\title{
Silent Expansion of Oil Palm Plantation: The Tragedy of Access Between Bundle of Right and Power
}

\author{
Bayu Eka Yulian ${ }^{1 *} \quad$ Arya Hadi Dharmawan ${ }^{2} \quad$ Endriatmo Soetarto $^{2} \quad$ Pablo Pacheco $^{3}$ \\ 1.Rural Sociology Study Program, Faculty of Human Ecology, IPB University, Kamper Street IPB Darmaga \\ Campus, Bogor, West Java, Indonesia 16680 \\ 2.Department of Communication and Community Development Sciences, Faculty of Human Ecology, IPB \\ University, Kamper Street IPB Darmaga Campus, Bogor, West Java, Indonesia 16680 \\ 3.Center for International Forestry Research, Situ Gede, Bogor, West Java, Indonesia
}

\begin{abstract}
The Expansion of oil palm plantations is often performed on a large scale of the state front stage, carried out through the operation of big capital, supported by licensing documents and using the legal basis of the state law in the form of land cultivation right (hak guna usaha). This phenomenon is an expansion of oil palm plantations which have been understood by the public as a form of open expansion. This research is using a mix of qualitative and quantitative methods which have found that there had been an expansion practice in other form, namely the silent expansion. This silent expansion is a form of tragedy of access where actors can establish oil palm plantations without the bundle of rights that are legal, but using a bundle of power behind the failure of state control over state property right. The expansion is done quietly, under-the-table, within a small area, without legal permit documents. In the final section, this paper describes the institutional response to the problem of silent expansion using formal policy instrument approach.
\end{abstract}

Keywords: Bundle of power, bundle of right, silent expansion, state failure, tragedy of access

DOI: $10.7176 / \mathrm{JESD} / 11-6-08$

Publication date:March $31^{\text {st }} 2020$

\section{Introduction}

The world's palm oil production continues to increase since 1960 due to the global demand for Crude Palm Oil (CPO) continues to increase (Corley 2009; Mielke 2012). Palm oil in Southeast Asia, especially in Indonesia has become one of the commodities revenue contributor to the national income and national economic growth (Wicke et al. 2011). Increasing global demand for CPO is proportional to the expansion of oil palm plantations. In 2000 the total expansion of oil palm plantations covering an area of 4 million hectares, doubled to 8 million hectares in 2010. To date the total expansion of oil palm plantations which were officially recorded by the state as of 2017 is in an area of 14.03 million hectares (Directorate General of Plantation 2018).

The expansion of oil palm plantations covering a total of 14.03 million hectares in Indonesia is carried out by a variety of actors, namely 1 ) a large scale plantation own by private company (PBS) by $55 \%$ or covering an area of 7.707.164 hectares, and 2) smallholders (PR) of $40 \%$ or an area of 5.613 .241 hectares, and 3) a large scale plantation own by state company (PBN) of 5\% or an area of 710.169 hectares. Oil palm expansion by large-scale plantations (either by PBS and PBN) presents a new problem in land use that is causing land disputes between companies and local communities, due to the location permit $(L P)$, the plantation business permit (IUP), and the land cultivation right $(H G U)$ issued by the state to the company have raised up overlapping ownership claims with traditional or local people (Calchoster et al. 2006; Sawit Watch 2015).

In addition to providing a positive impact on the national economy, on the other hand the expansion of oil palm plantations is one of the factors that cause changes in the ecological landscape and land use. For example, changes in land cover (land cover), land use (land use), deforestation and loss of biodiversity (Fitzhherbert et al. 2008; Obidzinki et al. 2012; Potter 2015).

Due to changes in the ecological landscape and land use are ultimately the expansion of oil palm plantations changed the livelihood system of village communities around oil palm plantations (McCarthy 2010; Rist et al. 2010; Sayer et al. 2012; Orsato et al. 2013; Lee 2013; Gatto et al. 2015). The changing of land cover and land use also have consequences on the people's livelihood system, from well-established local farming system into the circuit of palm oil production (Yulian et al. 2017).

Currently there are 2,3 million hectares of oil palm plantations located in the forest area which is a forbidden area for the cultivation of oil palm plantations (Minister of Environmental and Forest 2018) ${ }^{1}$. This means that there are illegal activities in the cultivation of oil palm plantations that do not coincide with the designation. In the state legal perspective, the cultivation of oil palm plantation activities to be conducted outside the forest area namely other use area (APL) or not the forest areas. For oil palm plantations intended to cultivate oil palm plantations in

\footnotetext{
${ }^{1}$ Statement from Minister of Environmental and Forestry in: https://www.mongabay.co.id/2018/10/20/menteri-lingkungan-bakal-evaluasi-23juta-hektar-kebun-sawit-di-kawasan-hutan/
} 
forest areas must obtain a discharge permit or forest area lease from the Indonesian government.

The big question is who are the performing actors and how does the oil palm plantation expansion work. This paper describes and offers a new debate about the operation of oil palm plantation expansion referred to as the silent expansion with the emphasizing on the problem between the right and access to the expansion of oil palm plantations.

\section{State of Problem and Urgency}

All this time, the debate about the expansion of oil palm plantations that come to the surface is about the occuring expansion on a large scale which led to changes in land use (Fitzhherbert et al. 2008; Obidzinki et. al. 2012; Potter 2015), altering the rural livelihood system (McCarthy 2010; Rist et al. 2010; Sayer et al. 2012; Orsato et al. 2013; Lee 2013; Gatto et al. 2015; Yulian, et al. 2018), is open in a public space, confronted between companies and local/rural communities, inducing social conflict (Calchoster et. al. 2006; Sawit Watch 2015). The actors who performed the expansion of plantations are diverse, not only large-scale oil palm plantations (company or state own plantation), but the invisible hand of smallholders or on behalf of smallholders are also do the same on a small scale, fragmented, in silence, also has the same impact on changing the ecological landscape, land use, and use of land as large-scale oil palm plantations.

Indonesia has policy in Regulation of the Minister of Agriculture Number 98 Year 2013 on Guidelines for Plantation Business Permit that governs and binds actor in both smallholder and large-scale enterprises. Oil palm expansion is a series of policy processes to be complied by the actors so that the plantation activities are recognized by the state and legally conforming. In regard with the Minister of Agriculture No. 98 Year 2103 regulation on Guidelines for Licensing of Plantation that for plantations that have area less than 25 hectares it shall have STDB (Plantation Registration Certificate for Smallholder) which is the authority of the Bupati (head of district). ${ }^{1}$ Furthermore for the large plantation business expanses more than or equal to 25 hectares are required to have Plantation Business Permit (IUP). ${ }^{2}$ Furthermore, after IUP company must have Land Cultivation Right (HGU) as the base of the concession rights. On the Land Cultivation Right Policy stated that individuals can be given the concession for a minimum area of 5 hectares and a maximum of 25 hectares. ${ }^{3}$ When an individual wants to plant on an area of 25 hectares, he/she can not be given the concession and should be transformed into a legal entity/company. So that the concession granted later on is Land Cultivation Right (HGU) of legal entity and he/she shall reorganize the earlier IUP.

Interesting problem is the expansion of oil palm plantations in the absence of clear title, the case in which the actors to expand without any STD-B and HGU. This phenomenon occurs not only because of the failure of the state in controlling the state property right, but the power that works behind the tragedy of access that is silent expansions.

\section{Methodology \\ 3.1 Methods}

This research uses a mix of qualitative and quantitative methods. Combination process is not a random "mix up" without a pattern, but use them gradually to understand the social reality in the countryside. According to Creswell (2009), the choice of combination strategies in the form of strategy mixed method sequential/stages (sequential mixed methods) which are procedures included the attemp to combine the obtained findings from one method to the discovery of other methods with the aim of complementing one another.

This research conducted with qualitative methods in advance to get an overview of the process of oil palm plantations expansion that enable to recognize the doers (actors), what are the implemented strategies. Through in-depth interviews and particpants observation on how the process of oil palm plantations expansion can be captured. Further quantitative approach carried out through a survey of 289 respondents to see the pattern of smallholder oil palm plantation expansion accomplishments and changes in household income system.

This research was conducted in four villages in the district of KK, East Kalimantan Province. The four villages, namely the village of MKU and MKI are located in MK sub-district. Then the PP and LBH village in the subdistrict of KB. The four villages have deliberately chosen in the consideration of the sociographic conditions and agro-ecosystems associated with oil palm plantations.

\footnotetext{
${ }^{1}$ Regulation of the Minister of Agriculture No.98 In 2013, Article 5, paragraph 1 states that Cultivation Crops as referred to in Article 3, paragraph (1) letter a with an area of less than 25 (twenty five) hectares be registered by the regent / mayor. Then Article 5 Paragraph 3 states that the Cultivation Crops listed as referred to in paragraph (2) shall be STD-B according to the format as specified in Attachment I which is an integral part of this Regulation. The next is detailed in the Director General of Plantations No. 105 / Kpts / PI.400 / 2/2018, of the STD-B.

${ }^{2}$ Regulation of the Minister of Agriculture 98 In 2013, Article 8 states that Cultivation Crops with an area of 25 (twenty five) hectares or more shall have IUP-B (Plantation Business Permit).

${ }^{3}$ Government Regulation No. 40 of 1996 Article 5 Paragraph 1 states that the minimum area of land that can be given leasehold is five hectares. Furthermore, Article 5 Paragraph 2 states the maximum area of land that can be given to an individual leasehold is twenty-five hectares. See also the Regulation of the Minister of Agrarian and Spatial/National Land Agency No. 7 Year 2017 concerning regulation and Procedures for HGU.
} 


\subsection{Research Location: Setting and Context}

The four Villages of research location are the villages that were along the expansion of large-scale oil palm plantations. In addition, most of whose population are smallholders who have a living system which relies on the cultivation of land for agriculture-based, mix garden, oil palm plantations, and a variety of local agriculture. The village selection is based on the consideration of ecological and rural sociography in each village (see Table 1).

Table 1. Research site villages conditions

\begin{tabular}{|c|c|c|c|c|c|}
\hline \multirow{2}{*}{ No } & \multirow{2}{*}{$\begin{array}{c}\text { Important } \\
\text { Aspect }\end{array}$} & \multicolumn{2}{|c|}{ MK Sub Distric } & \multicolumn{2}{|c|}{ KB Sub Distric } \\
\hline & & MKU Village & MKI Village & PP Village & LBH Village \\
\hline 1 & $\begin{array}{l}\text { Population } \\
\text { and Etnicity }\end{array}$ & Kutai & $\begin{array}{l}\text { Kutai and Migrants } \\
\text { (Java and Lombok) }\end{array}$ & Dayak Tunjung & $\begin{array}{l}\text { Dayak Modang \& } \\
\text { Kutai }\end{array}$ \\
\hline 2 & $\begin{array}{l}\text { Agro- } \\
\text { ecosystem }\end{array}$ & $\begin{array}{l}\text { Peatland, swamp } \\
\text { land, rivers, and } \\
\text { mix garden }\end{array}$ & $\begin{array}{l}\text { Swamp land, rice } \\
\text { field, river, and mix } \\
\text { garden }\end{array}$ & River, and forest & River, and forest \\
\hline 3 & $\begin{array}{l}\text { Typologi of } \\
\text { Palm oil } \\
\text { Production }\end{array}$ & $\begin{array}{l}\text { Large-scale, } \\
\text { nucleus-plasma, } \\
\text { and independent } \\
\text { smallhodler }\end{array}$ & $\begin{array}{l}\text { Large-scale, } \\
\text { nucleus-plasma, } \\
\text { and independent } \\
\text { smallhodler }\end{array}$ & $\begin{array}{l}\text { Large-scale, } \\
\text { nucleus-plasma, } \\
\text { and independent } \\
\text { smallhodler }\end{array}$ & $\begin{array}{l}\text { Large-scale and } \\
\text { independent } \\
\text { smallhodler }\end{array}$ \\
\hline 4 & Livelihood & $\begin{array}{l}\text { River fishermen, } \\
\text { farmers, planters } \\
\text { (smallholders) }\end{array}$ & $\begin{array}{l}\text { Fishermen, farmers, } \\
\text { planters } \\
\text { (smallholders) }\end{array}$ & $\begin{array}{l}\text { Farmers, planters, } \\
\text { (smallholders) and } \\
\text { hunting }\end{array}$ & $\begin{array}{l}\text { Farmers, fishermen, } \\
\text { planters } \\
\text { (smallholders), and } \\
\text { hunting }\end{array}$ \\
\hline 5 & Land use & $\begin{array}{l}\text { - } \begin{array}{l}\text { Non-forest } \\
\text { areas: }\end{array} \\
\text { seatlement, } \\
\text { agriculture, } \\
\text { mining, and } \\
\text { HGU } \\
\text { - Forest areas: } \\
\text { Nature } \\
\text { Reserves, and } \\
\text { Peatland } \\
\text { conservation. }\end{array}$ & $\begin{array}{l}\text { - Non-forest areas: } \\
\text { seatlement, } \\
\text { transmigration } \\
\text { area, agriculture, } \\
\text { and HGU } \\
\text { - Forest aeras: } \\
\text { Nature Reserves, } \\
\text { and Peatland } \\
\text { conservation. }\end{array}$ & $\begin{array}{l}\text { Non-forest areas: } \\
\text { seatlement, } \\
\text { agriculture, } \\
\text { mining, and HGU } \\
\text { - Forest aeras: } \\
\text { Logging } \\
\text { concession, } \\
\text { Industrial Timber } \\
\text { Estate, and } \\
\text { Protected forest }\end{array}$ & $\begin{array}{l}\text { - Non-forest areas: } \\
\text { seatlement, } \\
\text { agriculture, } \\
\text { mining, and HGU } \\
\text { - Forest aeras: } \\
\text { Industrial Timber } \\
\text { Estate, and } \\
\text { Protected forest }\end{array}$ \\
\hline
\end{tabular}

The first Expansion of large-scale oil palm plantations in the district of KK was commenced in 1993 by PT.REA in the sub-district of KB. PP and LBH village are villages in the sub-district of KB affected by oil palm plantation done by PT. REA. Compared with the other four villages, the PP and LBH villages are the villages that had the most prolonged contact with oil palm plantations then MKU and MKI. MKU village and MKI recent contact with the large-scale oil palm plantations were since the expansion done in 2006 by PT. PMM and PT. TJA.

Village relation with oil palm plantation companies provide different impact on the surrounding villages. PP and LBH village is a village that was once a village located around the woods with a wealth of roundwood (logs) abound. Village of PP is a rural village with ethnic Dayak Tunjung which has a living system depends on the forest through hunting-gathering, shifting cultivation (cultivation and forth), and paddy fields. But gradually since the 1980s until the 1990s when logging era until now amend rural livelihood systems. Similarly, LBH village, almost the same as the village of PP. But LBH village is the most impacted by the changing of living system due to the expansion of oil palm plantations, experiencing single source of income phenomenon which is palm oil dependant (Yulian et al. 2017). While the village of MKU and MKI are the villages where the people's living location are on the Mahakam and Kedang Rantau river bank. People's livelihood systems are now shifting towards increasingly relying on oil palm plantations (Figure 1). 


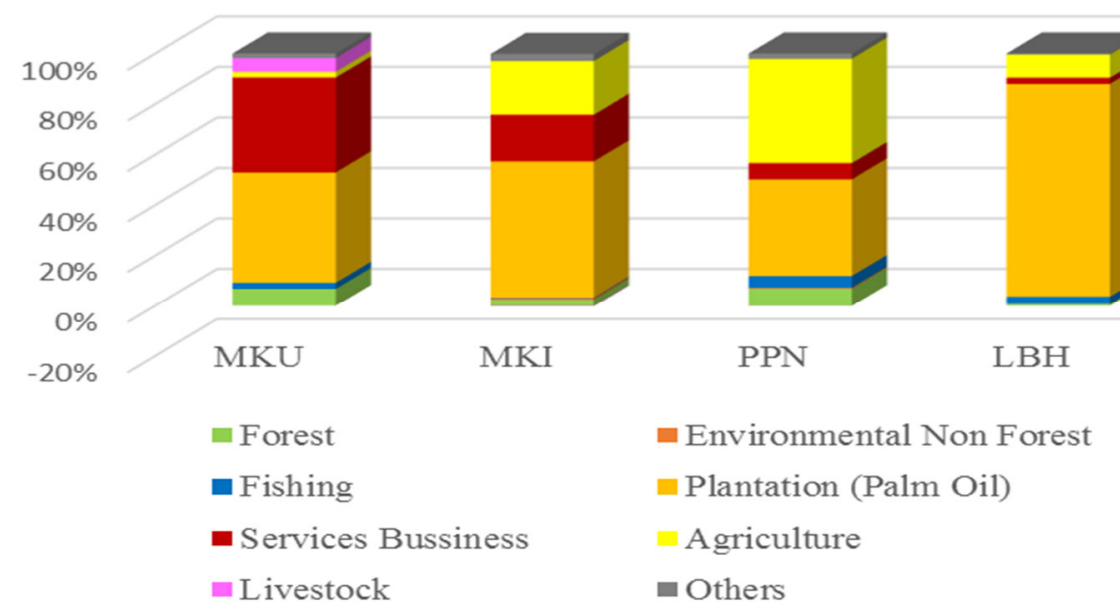

Figure 1. Rural Household Livelihood System: Go to Single Source of Income Depend on Palm Oil

Figure 1 above provides contextualization regarding the condition of the villages of the reserach site leads to a living system scenario increasingly dependent on oil palm plantations. It is an implication of the operation of the oil palm plantations expansion that give effect to the changes in livelihood systems of rural households. Rural economic system becomes increasingly open (open economic system) connected to the global circuit of the oil palm plantation system.

\section{Result}

4.1. Expansion and Teritorialization: Between Property Rights and Access

The debate between rights and access towards resources (in this paper is the land) is a binary debate in the space between the bundle of rights vs bundle of power (Ribot \& Peluso 2003; Sikor \&Lund 2009; Myers \& Hansen 2019). In the context of this paper, the expansion of oil palm plantations is analyzed through the relation between access-property with power-authority (Sikor \& Lund 2009). Property right (in a complex form of bundle of rights) is fundamentally understood as a legal basis for an actor to be able to take advantage of the land. Without the bundle of rights, then the actor can not take advantage of the land. The existence of recognition aspects of politicolegal encourage actors to gain legitimacy by which other actors have authority in this case is the state government. Although in daily practice of state formation, the state is not defined as a single actor and harmony, it has a degree and fragmented vertically and horizontally. Each actor in various levels of the country defines itself into become the most legitimate parties to have politico-legal authority. So that at the lowest level (village) or any other form, the land claim conflict between the politico-legal actors and others take place and has caused confusion.

In day to day practice it was found that without rights, it turns out that actors can utilize existing resources through a series of bundles of power in the form of technology, capital, markets, labor/employment opportunities, knowledge, authority, social identity, and social relations negotiations. According to Ribot \& Peluso (2003) property is the right to derive benefit from things, while access is the ability to derive benefit from things. The ability of the actor what is meant by the bundle of power that is ready to be played so that the actor can gain access to resources. Access reveals about who gets what, in what way, and when (the right time to play power in a certain momentum).

Furthermore, Ribot \& Peluso (2003) distinguish access mechanisms, into two types, namely 1) right-based access, an access mechanism based on rights. So there are two forms, namely legal access, through rules (law), formal authority and illegal access, namely access mechanisms obtained through ways that violate the rules (law) of formal authorities. Then the next type is 2) structural and relational access mechanisms that are based on structural strength and power relations which determine how an access can be achieved, controlled, and maintained, which includes factors (and various combinations) of the power operation.

The access mechanism ultimately results in an inclusion process for those who have access and exclusion for those who do not have access. Hall et al. (2011) explained that exclusion occurred because of the work of power of exclusion consisting of regulations, markets, legitimation, and force. The four factors become a unity that influences each other to become a force of coercion that is able to exclude others (in this case farmers). Regulations, for example, are through state policies related to granting rights (see Ribot and Peluso's legal access mechanism, 2003), granting concessions to oil palm plantations (HGU), land registration or certification. Next is the market which is the regulator of how commodity demand and supply and local-global economic networks. Then legitimacy through plantation revitalization programs, and in the name of fulfilling global food needs. In fact, it is not uncommon for exclusion to be carried out through military force or forms of thuggery to obviate the farmers 
from their land.

Tenure issues in Indonesia has become even more complex when it comes to discuss on property right regime. There is even a dualism of agrarian law at the site level between formal (state) law and local / customary law. Considering who has resources, Feeny et al. (1990) presents four categories of ownership (rights) of resources, namely open access (open/free access without social institutions/institutions), private property (individual rights ownership), customary property (group ownership/custom-customary) and state property (state ownership).

The authorization of natural resources in Indonesia is controlled (de jure) by the state through State Control Rights. However, the state's authorization experienced several modifications in the field of implementation (de facto). State property changes into become a common property, even in the absence of state control and management of these resources somehow "it seems" to be open access. Herein lies the problems related to the expansion of oil palm plantations which will be explained later as a form of silent expansion. The expansion of oil palm plantations in the end is a form of space territorialization to wit a mechanism by which actors seize space for monoculture crops by excluding other actors so that they can gain access and rights (Vandergeest \& Peluso 1995; Sikor \& Lund 2009; Peluso \& Lund 2011).

\subsection{The Silent Expansion of Oil Palm: Tragedy of Access}

The expansion of oil palm plantations is actually a series of processes to obtain rights and access legally. The process sequence depends on the performing actor. From this type of actor, then it can be profoundly mapped on the choice of strategies used in expanding oil palm plantations. Based on the results of field work and secondary data analysis of actors whom expand oil palm plantations can be divided into two major groups, namely 1) individuals and 2) companies (or legal entities). These individual actors can then be divided into two, namely 1 ) independent smallholders and 2) dependant smallholders who are then required by law to meet in a cooperative forum. Independent farmers are required to administer STD-B before starting their plantation business activities, while for dependant farmers they follow the process of managing HGU for plasma plantations which will be managed by plasma farmer cooperatives.

There are two types of corporate actors which can be categorized based on equity participation, namely 1) companies whose capital comes from domestic investment (PMDN) and 2) companies whose capital is from foreign investment (PMA). From the company management side divided into two, namely 1) private companies, those fully managed by the private sector without any state interference and 2) state companies managed by StateOwned Enterprises (BUMN). The process that must be taken by companies that want to build oil palm plantations is different from independent smallholders. The company must obtain a location permit (LP) in advance to find land that can be used for oil palm plantation development. On lands that already owned by other actors (individuals or groups), the company is obliged to settle the ownership rights. After the process of finding land through a location permit is completed, the company is obliged to take care of a plantation business permit (IUP), which will be used as the basis for managing the HGU as evidence of the right to do business on a land (Figure 2).

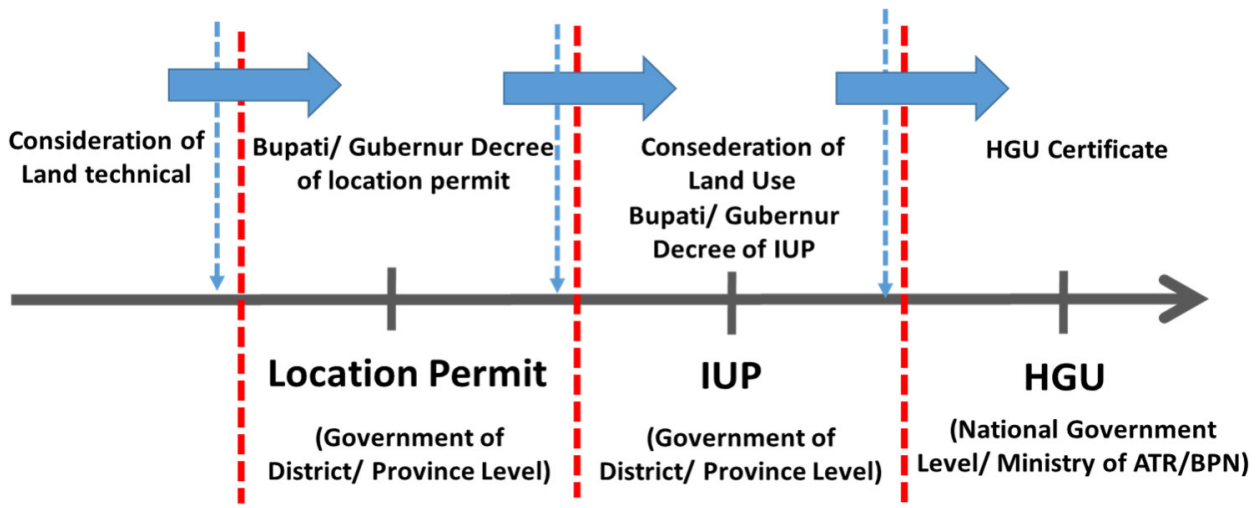

Figure 2. Legal mechanism for oil palm company

Based on Figure 2, Sunito \& Yulian (2013) explain that legal-ideal oil palm plantation companies are those that have LP, IUP, and HGU as well as existing oil palm plantations that have been develop. However, there are companies that only have LP, but their legal processes are not complete until IUP and HGU, as well as develop plantation. Some companies even have HGUs but there are no existing oil palm plantations.

Even though the reality shows that there are actors who are independent smallholders and companies that do not implement the licensing rules correctly. It means the development of oil palm plantations is legally problematic, because without property rights, it turns out that actors are still able to access land for oil palm plantation development. There is a denial of rights-based legal access mechanisms (Ribot \& Peluso, 2003), without recognition through politico-legal authority (Sikor and Lund, 2009). 
So that at least based on the conception of property right and access, it can be categorized as four typologies of actor conditions in the process of oil palm plantations expansion, namely: (I) Ideal conditions, which have rights and access to develop oil palm plantations; (II) Conditions that allow silent expansion, where actors do not have legal rights are able to access land discreetly using a set of "power" for the development of oil palm plantations; (III) The condition in which the actor experiences "exclusion", he does not have the right and access because it is excluded from other actors' rights; (IV) Conditions when experiencing land use and suitability technical problems, where actors have the right but are unable to access because of technological problems, overlapping land, land suitability, and land conflicts (see Figure 3).

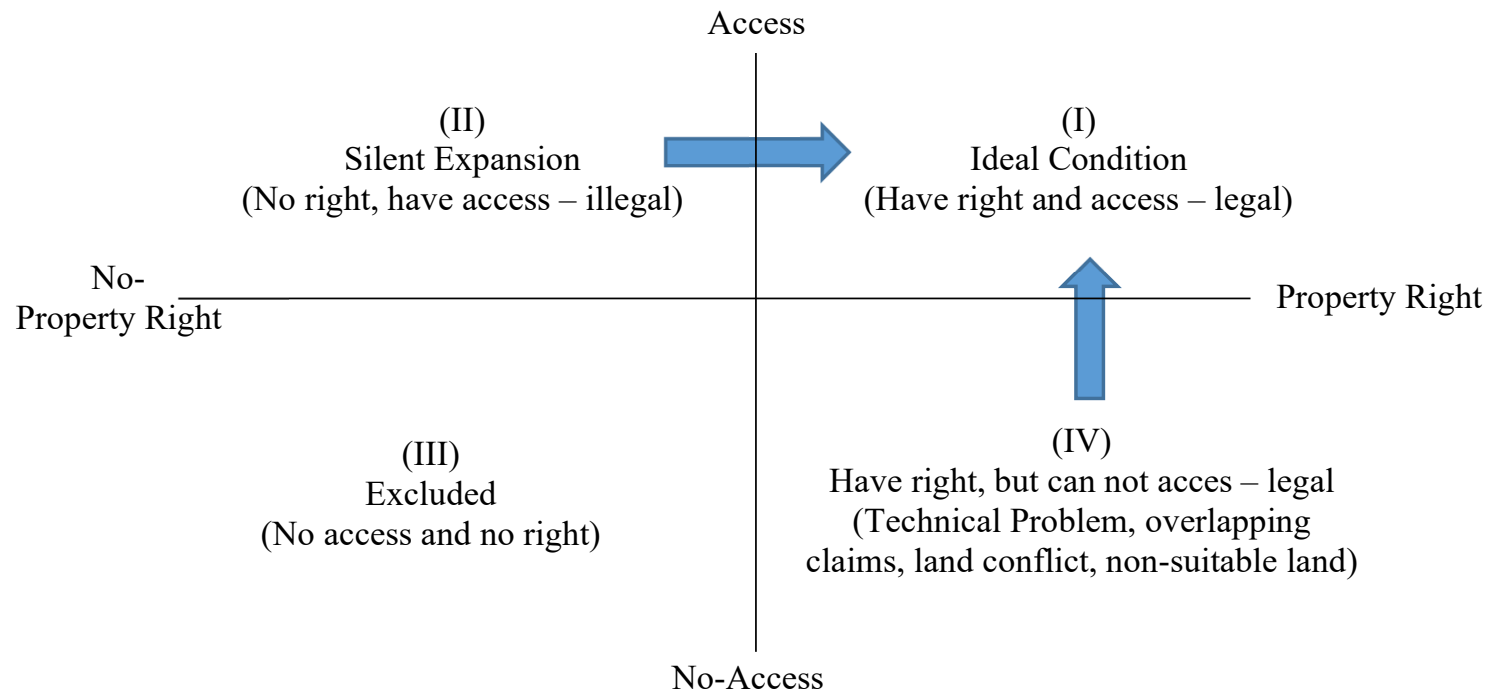

Figure 3. Four typologies of actors in the expansion of oil palm plantations

Based on Figure 3, Type I is a condition to be achieved in the context of sustainable oil palm plantations development. It is in type I that rights and access complete as mentioned by Ribot \& Peluso (2003); Sikor \& Lund (2009); Myers \& Hansen (2019) as legal access mechanisms occurrence. While in Type II and IV are oil palm plantations that have problems. Then type III is a condition where the actor is excluded by another actor. Specifically this type III is not discussed in this paper, but it remains a part of typology as a consequence of ideal typological distribution.

Type II, namely oil palm plantations that are built do not have a legal basis for legal rights, but by utilizing bundles of powers so that actors can access the land for the development of oil palm plantations. Type II in this paper is then conceptualized as silent expansion, where the expansion of oil palm plantations is carried out discreetly behind politico-legal authorities, between 2-25 hectares, fragmented (not one stretch of field), dominantly using non-certified seeds, built on the pattern of land use that is not supposed to. In addition to the bundle of power that works behind this silent expansion, another enabling factor is poor control of the state. So that there are conditions that appear to be open access to the state property right and or private property right which are blur spaces.

Based on the results of in-depth interviews and observations at the study site, this paper explains that the silent expansion of oil palm plantations is dominated by individual actors of independent farmers or individual actors driven by capital and technology owners. In carrying out such silent expansion, individual actors have social relations with the authorities at the village level (for example, obtaining land certificates/ certificate of employment) or other authorities such as customary/local institutions. In addition, in PP and LBH villages there is a program for distributing oil palm seedlings through the PPMD Program from the regional government in collaboration with corporate social responsibility programs from private companies. The oil palm seedlings planted by independent smallholders must then face the context of space density due to the expansion of plantation, forest and mining concessions by the company so there is no choice for independent smallholders to plant in areas that they say are empty and prone to enter the forest areas so it has an impact on deforestation. In addition to seeds, there are also owners of capital (not official/ legal banks) that supply money loans to independent smallholders as capital for the development of oil palm plantations. 


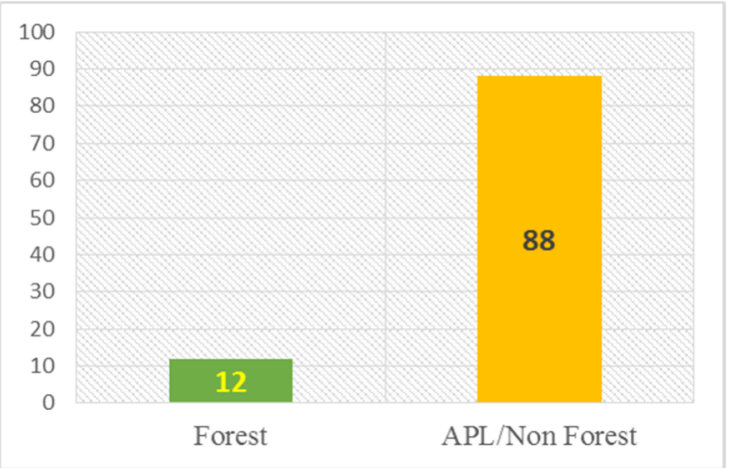

Figure 4. Percentage of respondents who build palm oil base on area function

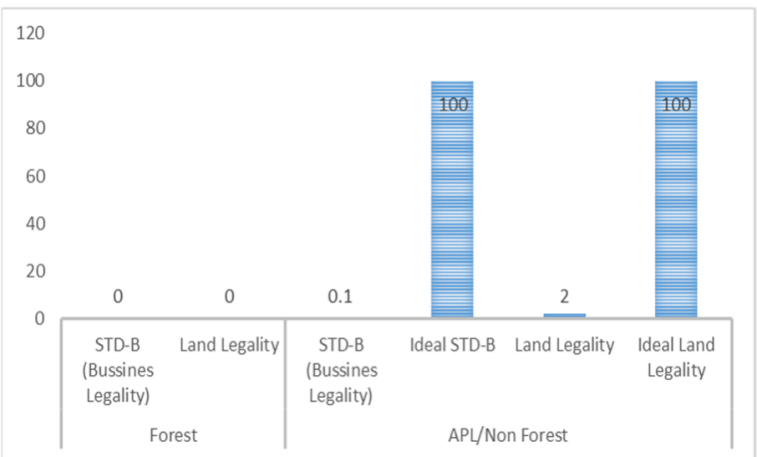

Figure 5. Percentage of respondents who have a land legality and STD-B by region

Based on Figure 4, it can be concluded that $12 \%$ of respondents build o1l palm plantations in torest areas, while $88 \%$ build in non-forest areas (APL) which are allocated for oil palm plantations. But as seen on Figure 5, in non-forest areas (APL) only $0.1 \%$ of respondents posses STD-B and only $2 \%$ posses certificates of land ownership in non-forest areas (APL). This means that oil palm plantations of the people encountering problems in terms of land legality and STD-B, let alone $12 \%$ in forest areas.

In the era of oil palm plantations expansion moratorium decreed by the President through Presidential Instruction No.8 Year 2018 concerning Delays and Evaluation of Licenses for Oil Palm Plantations and Increasing Productivity of Oil Palm Plantations. Indeed there are no new permits for oil palm plantations. The regulation was normatively responded by large-scale companies, with no process of submitting new permits for expansion. However, it does not mean that the expansion of oil palm plantations does not occur, but what happens is that the silent expansion of oil palm plantations carried out on behalf of independent smallholders continues to take place. Even the capital for the construction of oil palm plantations is supported by a middle man who gives loans to independent smallholders.

Despite a moratorium on oil has been set, the expansion of the
plantation can still be done. I got the information that the company is
currently difficult to find land, but still in need of fresh fruit bunch
(FFB). Fulfillment of the FFB to meet work quotas machine with FFB.
Now the company is no longer looking for land because it is difficult
and a lot of conflict with residents, but look for FFB. Now I am ready
to hold partnership in selling FFB to the company. Especially now
almost all areas of our village become palm oil plantations. We're not
here just to watch the palm oil plantation companies, but also involved
in oil palm plantations (TA, 52 years old).

Not only independent smallholders who have problems in Type II, plantation companies are also committing silent expansion in terms of the legality of IUP and HGU. Prior in getting an IUP, the oil palm plantation company must first obtain a location permit. The logic process of arranging location permit is in the authority of the local government through the One Door Management Integrated Service Agency. In general, the broad community did not get information about the openness of the location permit provided by the KK district government. On one hand, there is an example of the process in granting this location permit involving illegal transactions through bribery to local officials, as happened in cases of bribery made by PT. SGP to KK District officials related to granting location permits 5 .

Based on the results of in-depth interview with one of KK District officials, the logic of giving a location permit is a preliminary strategy that must be done by the company to acquire land. In general, the location permit is given as large as possible, with the provision that if there are rights of legal subjects already exist, the company must be released. Location permits are often given in thousands or even tens of thousands of hectares, but when continued towards IUP up to HGU the area shrinks dramatically because it cannot be opened and built entirely into oil palm plantations. Even the process of plantation business legality towards IUP to HGU has not yet been completed but the company has carried out plantation development in stages. HGU should be the basis of the right for the company to carry out plantation business, because the process of processing the old HGU is a phenomenon of "constitutional break" in the oil palm plantation permit process so that oil palm plantations are planted without HGU (while waiting for the HGU to issue).

In type IV, the main problem is that actors have rights to resources but there are other problems that prevent them from accessing. These problems include the overlap between the rights they have to build oil palm plantations with forest areas or the rights of others (resulting in land conflicts). In addition to the issue of space designation 
conformity, there are also technical problems in cultivation, for example land in slope areas that have steep slopes of more than 45 degrees, located on peat lands, and on nutrient-inadequacy land. An example is the case of oil palm plantation company PT. PP, which has had an area of 9,097 hectares of HGU, but until now has not carried out plantation development activities due to problems with land suitability and social conflict with the community.

\subsection{Dicussions for Managing The Expansion: Solution of Institution}

Problems such as those described above (see Figure 3) in Type II and IV must actually shift to Type I. To shift towards type I, there are two institutional approaches offered as a solution to the problem of oil palm plantations expansion. The approach is 1) through informal institutions and 2) formal institutions. An informal approach can be carried out through the operation of the local knowledge values and local wisdom, as well as using institutions such as the institution of the local economic system. Then the formal approach can be done through the operation of legal formal values.

The approach through informal institutions is experiencing problems amidst changes in the rural local economic system due to the expansion of oil palm plantations. One of the main characteristics of the expansion of oil palm plantations is similar to agriculture expansion, namely the nature of monoculture plants (Barralough \& Ghimire 2000). Its operations carry out land clearing (clearing land from previous vegetation, such as forests and mixed gardens) and then replanting the land with a single commodity (plant monoculture) in this case oil palm. The changing landscape due to the monoculture boom led to changes in the livelihood structure of rural households that increasingly relied on palm oil commodities (Yulian et al. 2017). In addition, the rural economy is increasingly experiencing exposure to the global economic system of oil palm plantations. As a matter of fact oil palm plantations has become economic pipe line that connects the lower circuit of rural economies with circuits over the global system of oil palm plantations. In addition to changing local values, it seems that the mutual cooperation has waned, the deterioration of local economic institutions with the replacement of local commodities into palm oil commodities. The condition of the global community through institutional market acceptance in the values of the Roundtable Sustainable Palm Oil (RSPO) requires institutional adaptation to sustainable oil palm plantations at the village level.

So there is no other option that Indonesia needs institutional solutions in the hands of the state through its legal instruments (formal legal). The state's political will and rules are available, namely the Minister of Agriculture Regulation No.11/2015 concerning the Indonesian Sustainable Palm Oil Certification System (Indonesian Sustainable Palm Oil Certification System/ISPO, Presidential Decree No.88/2017 concerning Settlement of Land Tenure in Forest Areas, Regulation of the Minister of Environment and Forestry No. 83/2016 concerning Social Forestry, Presidential Instruction No.8/2018 concerning Delays and Evaluation of Oil Palm Plantations Licensing and Productivity Enhancement of Oil Palm Plantations (Oil Palm Moratorium), and Presidential Decree No.86/2018 concerning Agrarian Reform. At least collaboration from the three sectoral regimes of the Indonesian government is needed to solve these existing problems related to Type II, and IV.

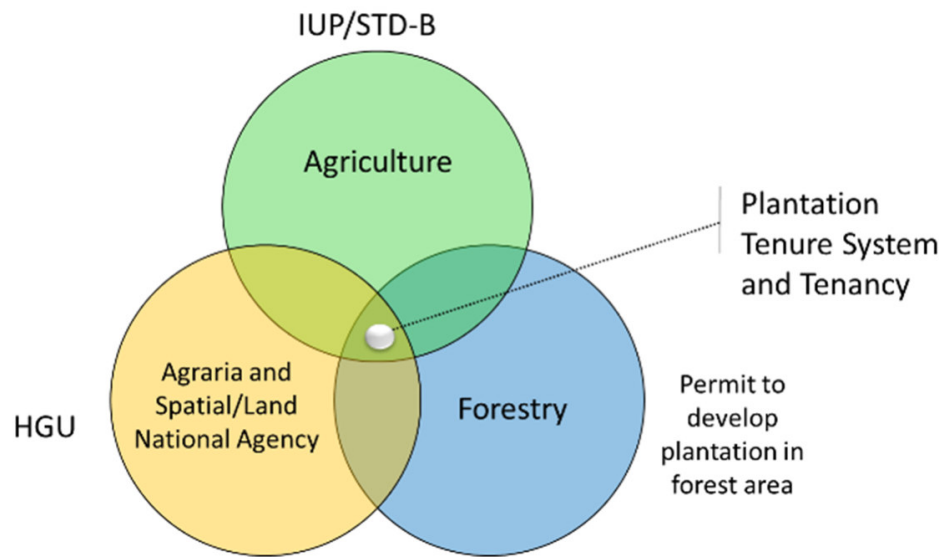

Figure 6. Orchestration Three Sectoral Regime for Oil Palm Tenure Issue Resolution via Formal Institution

Formal institutional solutions for resolving Type II and IV problems may use the policy instruments of Presidential Decree No.88/2017 concerning Settlement of Land Tenure in Forest Areas, Regulation of the Minister of Environment and Forestry No. 83/2016 concerning Social Forestry, Presidential Instruction No.8/2018 concerning Delays and Evaluation of Plantation Licenses Palm Oil and Productivity Enhancement of Oil Palm Plantations. The three instruments answer the problems of silent expansion that have experienced delays in the forest area. The choice is clear, namely 1) "recognisance" of oil palm plantations in the forest area (detaching the forest area status; then give it to the actor via land reform or social forestry program); 2) deconstructing oil palm plantations in forest areas, and punishing the perpetrators; 3 ) waiting for one crop cycle, cut down and there should be no plant for replanting; and 4) confiscating oil palm plantations in the forest area into state property (managed 
by PBN) and changing the status of the area. Resolving problems in Type II does not apply to large scale companies. Furthermore, after the above problems are resolved, the ISPO institution as an instrument of market acceptance can be applied so that the perspective of sustainable palm oil plantation development is able to come into reality. The perspective of sustainable palm oil in ISPO's perspective is elaborated through seven important indicators for plantation companies (see Permentan No.11 / 2015), namely 1) legality of plantation business (LP, IUP, and HGU); 2) plantation management; 3) protection of the use of primary natural forests and peat lands; 4) environmental management and monitoring; 5) responsibility for workers; 6) social responsibility and economic empowerment of the community; and 7) continuous improvement of business. While for smallholder plantations only four indicators are 1) the legality of planters (land legality and business STD-B); 2) plantations management organizations (farmer groups/cooperatives, knowledge of cultivation in accordance with good agricultural practices; legal seeds); 3) environmental management and monitoring (environmental preservation, biodiversity, suitability of space and regional functions); and 4) continuous improvement of business (sustainable production, productivity enhancement). By resolving oil palm plantation tenure issues and implementing ISPO for the future, the strategy of shifting existing problems in type II and IV with all kinds of complexity is possible.

\section{Reflection}

Silent expansion in the context of oil palm plantations development is a form of empty space between rights and access involving power played at certain momentum. Actors play a bundle of power to do territorialization of space and at the same time exclude other actors to control the land for the development of oil palm plantations. Even the process of space territorialization through silent expansion was able to overpower the regime of state property right, for example building oil palm plantations in forest areas that were normatively prohibited.

In the end silent expansion is a form of tragedy of access, where property rights become meaningless. Rightbased legal access mechanism does not occur. The politico-legal aspect is deconstructed by "semi-legal" actors but has the authority at the local level. Politico-legal to strengthen property right is no longer important to fight for, because without the right it turns out that the actor who did the silent expansion can access the land. This writing is an initial invitation to the reader to discuss and add some variety of silent expansion cases related to the development of oil palm plantations.

\section{Acknowledgement}

The research is supported by Oil Palm Adaptive Landscape (OPAL), project collaboration between IPB University, ETH Zurich, and Center for International Forestry Research.

\section{References}

Barraclough, S.L., \& Ghimire, K. B. (2000). Agricultural Expnsion and Tropical Deforestation: Poverty, International Trade, and Land Use. Earthscan Publications Ltd. UK.

Calchoster, M., Jiwan, N., Andiko, Sirait, M., Firdaus, A.Y., Surambo, A., \& Pane, H. (2006). The Promised Land, Palm Oil and Land Acquisition in Indonesia: Implications for Local Communities and Custom Society. Forest Peoples Program and Sawit Watch. Jakarta.

Corley, R. H. V. (2009). Palm Oil How Much do We Need ?. Environmental Science and Policy 12, 134-139.

Creswell, J. W. (2009). Research Design: Qualitative, Quantitative, and Mixed Methods Approach. Third Edition. SAGE Publications. California.

Directorate General of Plantation. (2018). Statistic of Plantation. Directorate General of Plantation, Ministry of Agriculture. Jakarta. Indonesia.

Feeny, D., Fikret, B., Bonnie, J., McCay, \& Acheson, J .M. (1990). The Tragedy of The Commons: Twenty-Two Years Later. Human Ecology, Vol. 18, No. 1, pp. 1-9.

Fitzherbert, E. B., Struebig, M. J., Morel, A., Danielsen, F., Brühl, C.A., Donald, P.F., \& Phalan, B. (2008). How Oil Palm Expansion Will Affect Biodiversity?. Trends in Ecology \& Evolution, Volume 23 , Issue 10, 538545

Gatto, M., Wollni, M., \& Qaim, M. (2015). Palm Oil Boom and Land Use Dynamics in Indonesia: The Role of Policies and Socioeconomic Factors. Land Use Policy 46 (2015): 292-303

Hall, D., Philip, H., \& Li, T. M. (2011). Power of Exclusion: Land dilemmas in Southeast Asia. National University of Singapore Press. Singapore.

Lee, J. S. H. (2013). Oil Palm Expansion in Indonesia: assesing Livelihood and Environmental Impacts From the Smallholder Sector. Dissertation ETH Zurich Sitzerland. No.21273.

Myers, R., \& Hansen, C. P. (2019). Revisiting A Theory of Access: A Review. Society and Natural Resources, DOI:10.1080/08941920.2018.1560522

McCarthy, J. F. (2010). Processes of Inclusion and and Adverse Incoporation: Oil Palm and Agrarian Change in Sumatra, Indonesia. Journal of Peasant Studies, 37: 4, 821-850.

Mielke. (2012). Global Supply, Demand, and Price Outlook for Vegetable Oils - Especially Palm Oil. Oil World. 
ISTA Mielke Gmbhm Hamburg.

Obidzinski, K., Andriani, R., Komarudin, H., \& Andrianto, A. (2012). Environmental and Social Impacts of Oil Palm Plantations and Their Implications For Biofuel Production In Indonesia. Ecology and Society Journal, 17.

Orsato, R.J., Clegg, S.R., \& Falcao, H. (2013). The Political Ecology of Oil Palm Production. Journal of Change Management, 13: 4, 444-459.

Peluso, N., \& Lund C. (2011). New Frontiers of Land Control: Introduction. The Journal of Peasant Studies 38 (4): 667-681.

Potter, L., (2015). Managing Oil Palm Landscape: A Seven Country Survey of The Modern Palm Oil Industry in Southeast Asia, Latin America and West Africa. Occasional Papper 122. CIFOR, Bogor, Indonesia.

Ribot, J., \& Peluso, N. (2003). A Theory of Access. Rural Sociology 68 (2): 153-181.

Sikor, T., \& Lund, C. (2009). Access and Property: A Question of Power and Authority. Development and Change $40(1): 1-22$.

Sayer, J.A., Ghazoul, J., Nelson, P., \& Boedhihartono, A.K. (2012). Oil Palm Expansion Transforms Tropical Landscapes and Livelihoods. Global Food Security 1 (2012): 114-119

Sunito, S., \& Yulian, B. E. (2013). HGU: The New Face of Domeinverklaring in Indonesia. Contributed Paper in Public Seminar on "Land Deals and Rural Transformation" by the University of Amsterdam, Department of Community Development IPB and Communication Sciences, and Sajogyo Institute. March 25, 2013. Bogor.

Vandergeest, P., \& Peluso, N. L. (1995). Territorialization and State Power in Thailand. Theory and Society 24: $385-426$

Wicke, B., Sikkema, R., Dornburg, V., \& Faaij, A. (2011). Exploring Land Use Changes And The Role Of Palm Oil Production In Indonesia And Malaysia. Land Use Policy 28, 193-206.

Yulian, B. E., Dhamawan, A. H., Soetarto, E., \& Pacheco, P. (2017). The Dilemma of the Rural Livelihood Household Around The Oil Palm Plantation in East Kalimantan. Sodality: Journal of Rural Sociology, Vol.5, No.3 December 2017. ISSN 2302-7525. DOI: https://doi.org/10.22500/sodality.v5i3.19398 